\title{
Passivation of Iron in Solutions Containing Borate Using Rotating Ring-Disc Measurements
}

\author{
Emilse M.A. Martini* ${ }^{\mathrm{a}}$, and Iduvirges L. Muller ${ }^{\mathrm{b}}$ \\ ${ }^{\mathrm{a}}$ Instituto de Química, Universidade Federal do Rio Grande do Sul, \\ Av. Bento Gonçalves 9500, 91501-970 Porto Alegre - RS, Brazil \\ ${ }^{\mathrm{b}}$ Departamento de Metalurgia, Universidade Federal do Rio Grande do Sul, \\ Av. Osvaldo Aranha, 99 - s.607, Porto Alegre - RS, Brazil
}

\begin{abstract}
Investigou-se o comportamento eletroquímico do ferro em soluções neutras de perclorato de sódio contendo pequenas concentrações de borato de sódio, através da técnica de voltametria cíclica e empregando-se eletrodo rotatório de disco e anel. Nas soluções de perclorato, a passivação do ferro ocorreu após o pico anódico correspondente à zona ativa, no qual foi observada a dissolução de espécies $\mathrm{Fe}^{2+}$ e $\mathrm{Fe}^{3+}$. Quando é adicionado borato à solução, tanto a densidade de corrente do pico anódico quanto a quantidade de espécies ativas de ferro solúveis diminuem. Para uma concentração constante de perclorato e borato, o aumento do $\mathrm{pH}$ do meio mostrou ser menos efetivo na promoção da passivação do ferro do que a presença de borato. Os resultados demonstraram que a interação entre o íon borato e a superfície eletródica ocorre por adsorção química, de acordo com a isoterma de Langmuir.
\end{abstract}

The electrochemical behavior of iron in neutral solutions of perchlorate and low borate concentrations was investigated using cyclic voltammetry and the rotating ring-disc electrode techniques. In solutions containing just perchlorate, iron passivation was observed at potentials higher than the potential of an anodic peak corresponding to the active range at which the dissolution of $\mathrm{Fe}^{2+}$ and $\mathrm{Fe}^{3+}$ species was detected. When borate is added to the solution, this anodic peak decreased as well as the amount of the active soluble species. The increase of $\mathrm{pH}$, keeping the borate and perchlorate concentrations constant, was found to be less effective at promoting iron passivation than the increase of borate concentration. The results demonstrated that the interaction between borate ion and the electrode surface occurs by chemical adsorption according to the Langmuir isotherm.

Keywords: iron passivity, borate passivity, anodic films

\section{Introduction}

During the last 30 years, the buffer sodium borate-boric acid has been intensively used as an electrolyte in many electrochemical studies that investigate the behavior of several metals and alloys, mainly iron, nickel, copper, cobalt and steel ${ }^{1-10}$. The concentrations of each component of this buffer are always high e.g. $0.1 \mathrm{~mol} / \mathrm{L}$ or higher, in order to promote a low ohmic drop in the solution. In these studies the borate buffer acts as support electrolyte or as a blank test to which the results of experiments using agressive anions, such as chloride and sulphate, could be compared. The borate buffer solution is often used in these studies because in this electrolyte the cathodic reduction of initial oxide formed in air is easy ${ }^{11}$ and the anodic passivation is very efficient ${ }^{11-18}$.

Nevertheless most authors have not investigated the influence of the borate anion on the studied metal dissolution and passivation processes. Some authors have considered this anion to be a corrosion inhibitor, mainly for iron and steel, and have explained its performance as a $\mathrm{pH}$ controller buffer ${ }^{11-18}$. Only a few authors have considered the borate anion as an adsorption inhibitor ${ }^{12-15}$ and studies in which this anion is used in small concentrations are very scarce ${ }^{12-13}$. This kind of study should be carried out when an adsorption inhibitor is investigated. No data in the litera- 
ture was found concerning the active species dissolution in the presence of borate.

The use of a rotating disc electrode presents several advantages because there is an important feature that distinghishes it from the other reaction surfaces in a flowing fluid, that is, the thickness of the hydrodynamic boundary layer is constant along the whole disc surface. This fact assures that the mass transport to any point of the disc surface is identical. Such a reaction surface is uniformly accessible from the standpoint of diffusion ${ }^{19}$.

Therefore, in experiments using RRDE, any soluble species produced at the disc, that is electrochemically active, could be homogeneously collected by the Pt ring and therefore identified by this way.

The equations for convective diffusion, derived from the general equation of Navier-Stokes, are simplified when the reaction site is the surface of a rotating disc. Such simplifications make the use of RDE very convenient in electrochemical experiments.

Nevertheless, the equations derived for RDE could not be applied for very small or very large values for the electrode rotation rate $(\omega)$. When $\omega$ is smaller than $100 \mathrm{rpm}$, the hydrodynamic boundary layer becomes large and approaches the disc radius. Under this condition, the derived equations are not followed. On the other hand, for values of $\omega$ larger than $10,000 \mathrm{rpm}$, the flow regime becomes turbulent. Values of the Reynolds number greater than $2 \mathrm{x}$ $10^{5}$ are not convenient for RDE experiments because this represents the limit for laminar flux conditions. This fact is important because when the flux becomes turbulent the equations of mass transport are also no longer valid.

For these reasons the range of $\omega$ generally used in RDE studies is between 100 and $10,000 \mathrm{rpm}^{21}$.

The aim of this study is to compare the electrochemical behavior of iron in a solution of sodium perchlorate $0.1 \mathrm{~mol} / \mathrm{L}$ containing or not small amounts of borate in the absence of its acid pair, as in this manner the borate buffering capacity is decreased. At these conditions the use of rotating ring-disc electrode is used in order to control the dissolution of active species before and after of borate addition.

\section{Experimental}

The working electrode consisted of a Gallard-Schlesinger $99.999 \%$ pure iron disc embedded in PTFE, with an exposed area of $0.1886 \mathrm{~cm}^{2}$. This electrode was polished on $\mathrm{SiC}$ paper down to grade 1000 and $0.1 \mu \mathrm{m}$ alumina paste, and then washed, rinsed with bidistilled water and ethanol and dried. A potential of $-1600 \mathrm{mV}$ in relation of a satured calomel electrode (SCE) was applied for $10 \mathrm{~min}$ in the same working solution for reduction of air-formed films. For the rotatory ring-disc electrode (RRDE) experiments, a plati- num ring with an area of $0.0651 \mathrm{~cm}^{2}$ with a collection factor of $0.26^{21}$ has been used. All experiments have been run with the electrode rotating at $1000 \mathrm{rpm}$. The solutions used were $0.1 \mathrm{~mol} / \mathrm{L}$ sodium perchlorate to which 0 to $3000 \mathrm{ppm}$ borax had been added. Whenever necessary, the $\mathrm{pH}$ was adjusted by adding a solution of $0.1 \mathrm{~mol} / \mathrm{L} \mathrm{NaOH}$. All chemicals where analytical grade. The equipment consisted of a Pine bipotentiostat Model AFRDE 5, a BBC Model SE 780 X-Y recorder and a Pine analytical rotor. The electrolytical cell consisted of a pyrex glass flask with four entrances. Potential has been measured against a saturated calomel electrode (SCE) provided with a double sintered glass junction and a Luggin capilary. The potentials are referred to it throughout the text. The counterelectrode was a platinum wire. The experiments have been run at room temperature and under a $\mathrm{N}_{2}$ atmosphere.

\section{Results and Discussion}

Voltammetric experiments with RRDE in $0.1 \mathrm{~mol} / \mathrm{L}$ sodium perchlorate with the $\mathrm{pH}$ adjusted to 9 were carried out. Figure 1.a shows the results of disc current $i_{d}$ for the two first cycles obtained at a scan rate of $50 \mathrm{mV}$ $\mathrm{s}^{-1}$. The ring current detected along the potential scan of the disc under oxidizing $(+600 \mathrm{mV})$ or reducing conditions $(-800 \mathrm{mV})$ is also shown. The voltammogram in perchlorate solution is characterized by an extensive active region with one single current peak $\left(\mathrm{P}_{\mathrm{A}}\right)$, after which the electrode passivates. Along both the active as well as the passive zones iron dissolution occurs as $\mathrm{Fe}^{2+}$ species as is shown by peaks 1, 2 and 3 on the ring curve (Fig. 1.b). Dissolution by formation of $\mathrm{Fe}^{3+}$ species is also observed during the oxidation of the disc electrode (Fig. 1.c). The total anodic charge evaluated by integrating the $i_{d}$ curve referring to the first cycle is $79.6 \mathrm{mC} \mathrm{cm}^{-2}$. The charge under the $\mathrm{i}_{\mathrm{r}}$ ring curves, kept in oxidizing conditions as well as in reducing conditions during the positive going scan allows calculation of the total charge density involved in the dissolution processes by both $\mathrm{Fe}^{2+}$ and $\mathrm{Fe}^{3+}$ species, as equal to $4.3 \mathrm{mC} \mathrm{cm}^{-2}$. This value corresponds to $5.4 \%$ of the total anodic charge of the disc. Thus, the anodic peak presented on the disc voltammogram corresponds to the formation of a film containing $\mathrm{Fe}(\mathrm{II})$ species, with some simultaneous transport of $\mathrm{Fe}^{2+}$ species to the solution. As the potential increases, part of the $\mathrm{Fe}$ (II) of the film oxidizes to $\mathrm{Fe}(\mathrm{III})$, with simultaneous dissolution as $\mathrm{Fe}^{2+}$ and $\mathrm{Fe}^{3+}$ species. The formation of these Fe(III) species on the surface leads to passivation, while the film forms at the metal / film interface and partially dissolves at the film / solution interface. These facts indicate that Fe(II) species are constantly produced during all the anodic region of potentials. Inverting the potential scan a significant hysteresis confirms the existence of the passive film, which suffers a partial reduction represented by a cathodic peak 
of small intensity $\left(\mathrm{P}_{\mathrm{C}}\right)$. After one complete voltammetric cycle the total cathodic charge is smaller than the anodic one, even taking into account the dissolutive processes. This fact shows that the film reduction occurs only partially or otherwise at potentials as negative as that of $\mathrm{H}_{2}$ evolution. During the reduction process, $\mathrm{Fe}^{2+}$ species are caught on the ring (peak 4, Fig. 1.b). Probably part of the Fe(III) species of the film are reductively dissolved to $\mathrm{Fe}^{2+}$ species.

With continuous potential cycling and also increasing scan rate, both the anodic as well as the cathodic peak increase and separate from each other. Thus the processes represented by peaks $\mathrm{P}_{\mathrm{A}}$ and $\mathrm{P}_{\mathrm{C}}$ correspond to a redox pair, which becomes more irreversible with cycling or with increasing potential scan rate. The growing distance between anodic and cathodic peaks may be related with the ageing processes of the film ${ }^{22}$, which dehydrates, getting less conductive and rendering its reduction and further reoxidation more difficult. The increase of the intensity of these peaks with the progressive cicling is a probable consequence of increasing the active area of the electrode, due to higher rugosity of the surface, resulting from the dissolution processes.

Thus iron passivation in perchlorate solutions is not an efficient process because it requires the transport of a great amount of charge. Perchlorate anion is not expected to adsorve on the metallic surface and thus the film-forming mechanism does not occur by a topochemical pathway, but probably by precipitation, requiring the species saturation near the electrode, with high current transport.

Different amounts of borate, from 500 to $3000 \mathrm{ppm}$ were added to the $0.1 \mathrm{~mol} / \mathrm{L}$ sodium perchlorate solution and Fig. 2 shows the obtained voltammograms in the same

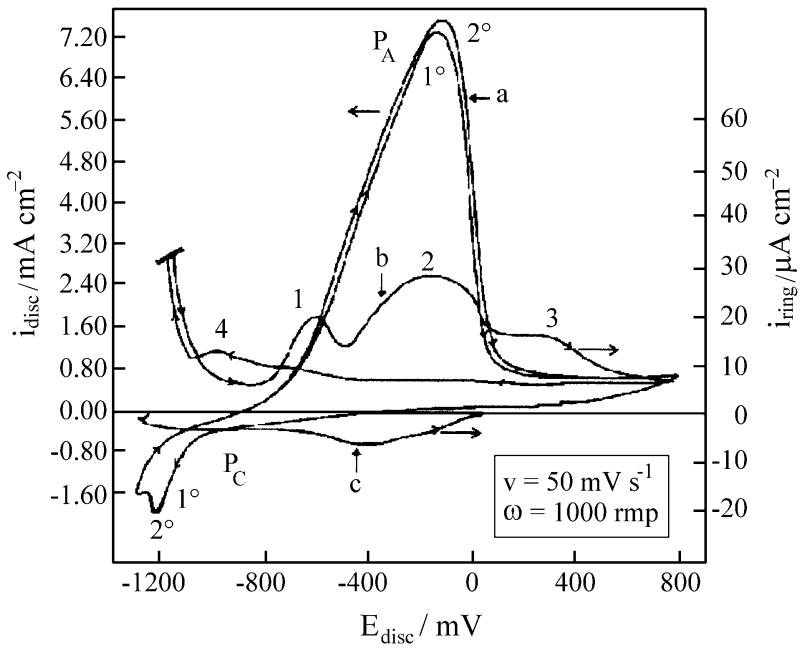

Figure 1. a - Cyclic voltammograms of iron in $0.1 \mathrm{~mol} / \mathrm{L}$ sodium perchlorate $(\mathrm{pH})$. First and second cycles.

b - Ring current density $\left(E_{\text {RING }}=600 \mathrm{mV}\right)$ during disc potential scan, showing four peaks (1, 2, 3 and 4).

$\mathrm{c}-$ Ring current density $\left(\mathrm{E}_{\mathrm{RING}}=-800 \mathrm{mV}\right)$ during disc potential scan. condition as those in Fig. 1. The anodic peak $\mathrm{P}_{\mathrm{A}}$ as well as the cathodic peak $\mathrm{P}_{\mathrm{C}}$ diminish according to borate concentration and their potentials are shifted to more positive values. In the inverse scan, the curves cross the absciss axis always at about the same potential $(-400 \mathrm{mV})$, which may indicate that the same species is reduced under all conditions.

The influence of consecutive potential cycling on the voltammetric profiles has been verified for borate concentrations from 1000 to $3000 \mathrm{ppm}$. Figure 3 presents the results obtained for the first five cycles in the perchlorate

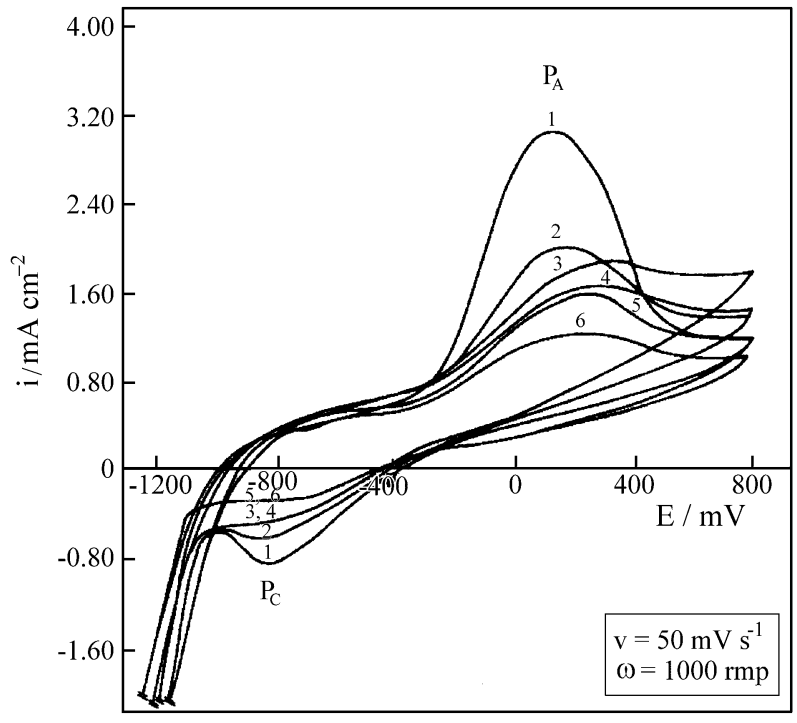

Figure 2. Cyclic voltammograms of iron in $0.1 \mathrm{~mol} / \mathrm{L}$ sodium perchlorate (pH 9) with the addition of borax: 1 - 500 ppm; 2 - 1000 ppm; 3 - 1500 ppm; 4 - 2000 ppm; 5 - 2500 ppm; 6 - 3000 ppm.

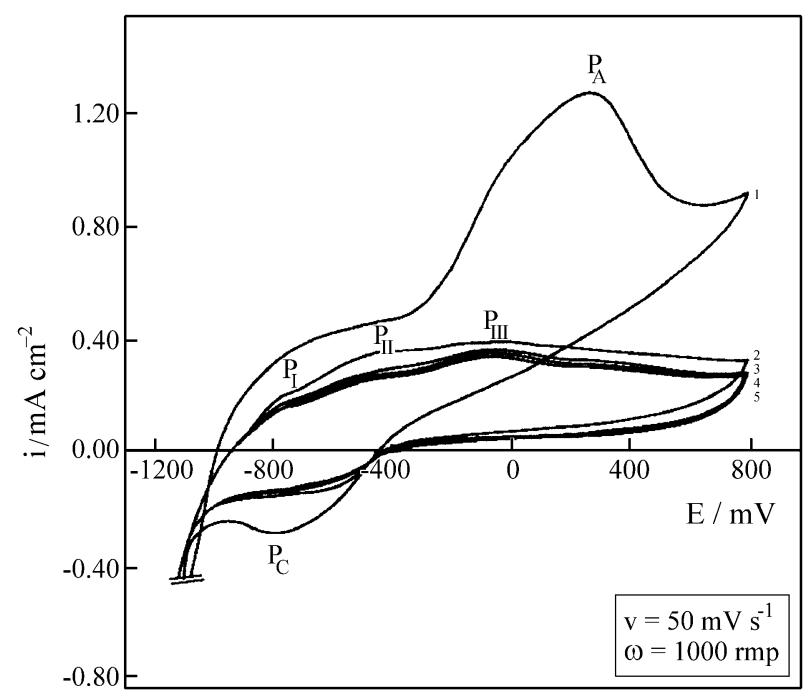

Figure 3. Cyclic voltammograms of iron in $0.1 \mathrm{~mol} / \mathrm{L}$ sodium perchlorate +2500 ppm borax (pH 9). $\mathrm{P}_{\mathrm{A}}$ and $\mathrm{P}_{\mathrm{C}}$ : anodic and cathodic peaks in the first cycle. $\mathrm{P}_{\mathrm{I}}, \mathrm{P}_{\mathrm{II}}$ and $\mathrm{P}_{\mathrm{III}}$ anodic shoulders in follwing cycles. 
solution containing $2500 \mathrm{ppm}$ of borate. The results shown in Figs. 2 and 3 allow the demonstration of the inhibiting properties of borate ion. As its concentration increases, passivation becomes more efficient with a smaller anodic charge transport. The comparison between the first cycle and the following ones shows that the anodic peak $\mathrm{P}_{\mathrm{A}}$ is substituted by three anodic shoulders, $\mathrm{P}_{\mathrm{I}}, \mathrm{P}_{\mathrm{II}}$ and $\mathrm{P}_{\mathrm{III}}$ (Fig. 3 ), with smaller current densities. The second cycle and the following ones are identical in shape to the first cycle obtained for iron in $0.1 \mathrm{~mol} / \mathrm{L}$ borax solution (Fig. 4) under the same conditions, which are associated with passive film fomation. Thus, it seems to exist competitivity among the actions of the different anions: if borate cannot avoid metallic dissolution and the consequent film formation from species precipitation in perchlorate solution, at least it can make it more difficult, polarizing the process that occurs at $\mathrm{P}_{\mathrm{A}}$. In the following cycles, the formed film is not totally reduced, and suffers an ageing processes through dehydration, which makes it more resistive. This film acts as a physical barrier regarding the dissolution of iron in the presence of perchlorate.

The experiments using RRDE, with the ring electrode either kept under oxidizing $(+600 \mathrm{mV})$ or under reducing conditions $(-800 \mathrm{mV})$ during the disc potential scan, allowed the verification of the influence of borate on the dissolution processes. Figure 5 shows the results obtained in solutions of 1000, 2000 and $3000 \mathrm{ppm}$ of borate for the first cycle of the disc. In the forward scan, $\mathrm{Fe}^{2+}$ species result from the dissolution of the disc at $-650 \mathrm{mV}$, that corresponds to the active region. The amount of $\mathrm{Fe}^{2+}$ species tends to decrease as borate concentration increases. Also $\mathrm{Fe}^{3+}$ species are formed at $-630 \mathrm{mV}$. No corresponding current has been detected by the ring in the solution containing the highest concentration of borate (3000 ppm). In the reverse scan, the ring registers $\mathrm{Fe}^{2+}$ dissolution during the film reduction, at a more negative potential than in the

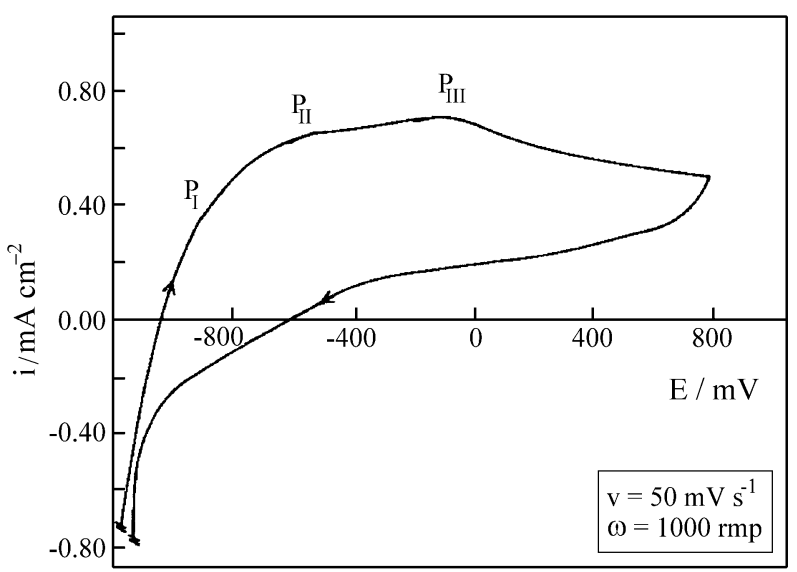

Figure 4. Cyclic voltammogram of iron in $0.1 \mathrm{~mol} / \mathrm{L}$ borax solution $(\mathrm{pH}$ 9). PI, PII and PIII: anodic shoulders. PC: cathodic current region. absence of borate. The ring electrode current also diminishes as borate concentration increases, as in the direct scan.

The results obtained with the ring-disc electrode permit the comparison of the metal dissolution processes in the absence as well as in presence of borate. This anion seems to prevent the dissolution of iron as $\mathrm{Fe}^{2+}$ and $\mathrm{Fe}^{3+}$ species at potentials higher than $-400 \mathrm{mV}$, exactly when there is a greater dissolution in the medium containing only perchlorate. Thus borate stabilizes a film formed at more negative potentials, corresponding to the active zone, and also helps the film in preventing the dissolution process at higher potentials (Fig. 1.b, peak 3).

The charge, evaluated by integrating the ring current along the oxidation process, permits the calculation of the fraction of the total charge transferred at the disc referring to the dissolution processes. Thus, in the solution containing $1000 \mathrm{ppm}$ borate, this fraction corresponds to $1.7 \%$ and diminishes to only $1.1 \%$ in solutions containing 2000 or $3000 \mathrm{ppm}$. This fact shows that the borate inhibiting action on the dissolution processes does not increase remarkably with higher concentrations.

The influence of $\mathrm{pH}$ on the electrochemical behavior of iron in perchlorate+borate solutions has also been verified. The borate concentration was fixed at $1000 \mathrm{ppm}$, potential scan rate was kept at $50 \mathrm{mV} \mathrm{s}^{-1} \cdot \mathrm{pH}$ values from 9 to 12 have been tested by adding $\mathrm{NaOH}$ to the solutions. As the $\mathrm{pH}$ increases, the current referring to peaks $\mathrm{P}_{\mathrm{A}}$ and $\mathrm{P}_{\mathrm{C}}$ decreases. The anodic peak potential is shifted to more positive values and the cathodic peak to more negative values. The increase of $\mathrm{pH}$ causes a polarization of the processes represented by peaks $\mathrm{P}_{\mathrm{A}}$ and $\mathrm{P}_{\mathrm{C}}$, increasing thus the redox process irreversibility. The anodic and cathodic
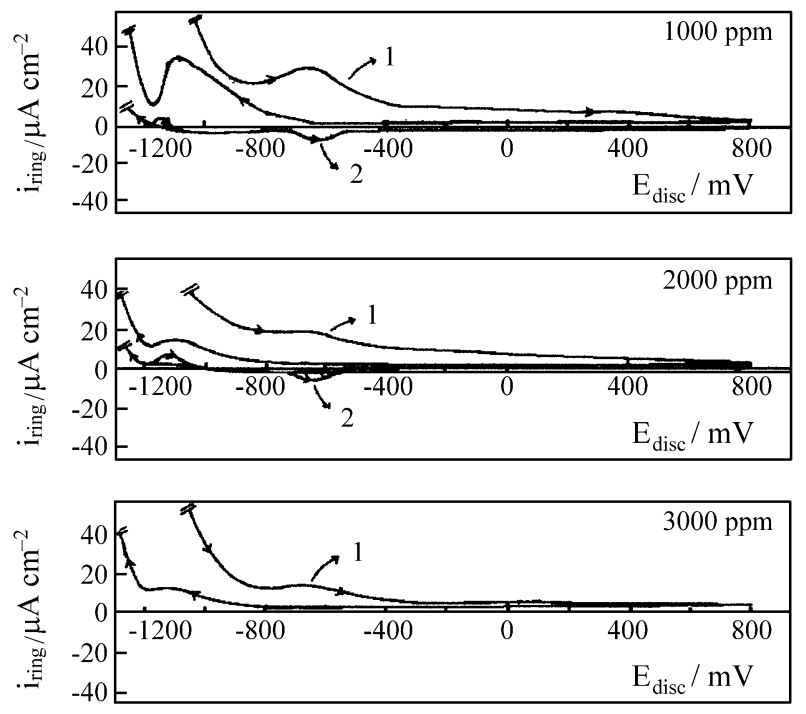

Figure 5. Platinum ring current density variation with disc potential scan in $0.1 \mathrm{~mol} / \mathrm{L}$ sodium perchlorate with borax addition $(\mathrm{pH} 9) .1-$ ERING $=$ $+600 \mathrm{mV} ; 2$ - ERING $=-800 \mathrm{mV}$. 
current densities also decrease as $\mathrm{pH}$ increases. The presence of oxydriles improves borate inhibiting action.

Figure 6 presents the effects of borate concentration and $\mathrm{pH}$ on the density of the anodic current peak $\left(\mathrm{i}_{\mathrm{PA}}\right)$ and of the corresponding peak potential ( $\left.\mathrm{E}_{\mathrm{PA}}\right)$. The variation of $\log$ $\mathrm{i}$ with $\log \mathrm{C}_{\mathrm{BORATE}}$ is also shown, where $\mathrm{i}$ is the anodic current density at $-100 \mathrm{mV}$ in the Tafel region of the anodic peak $\mathrm{P}_{\mathrm{A}}$ (Fig. 3). The straigt line obtained has a linear correlaction coefficient of 0.96 and an inclination of -0.31 , which corresponds to the reaction order of the oxidation process with respect to the borate anion. The negative value indicates the inhibiting character of this anion. From current densities evaluated at the same potential $(-100 \mathrm{mV})$ but for different $\mathrm{pH}$ with fixed borate (1000 ppm) and perchlorate

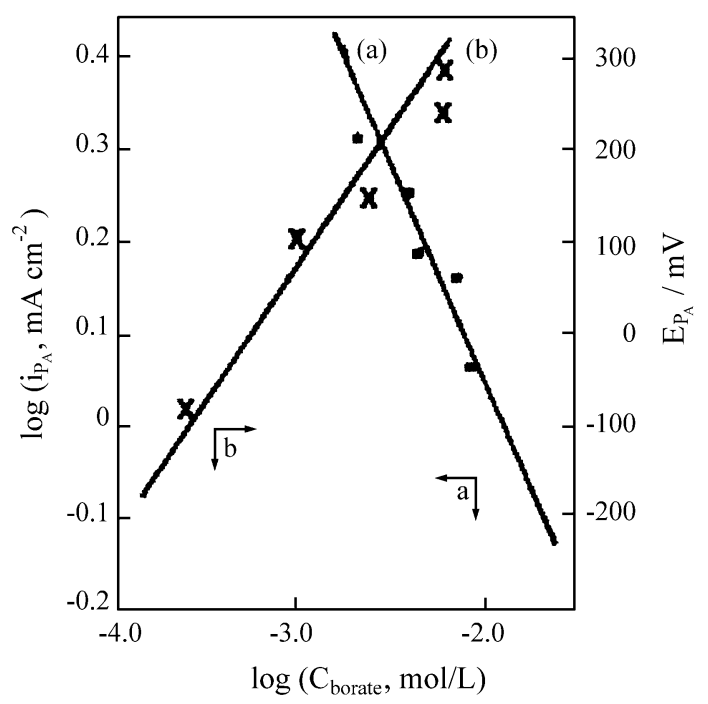

Figure 6.1. a. Variation of anodic peak current density with borax concentration.

b. Effect of borax concentration on the anodic peak potential.

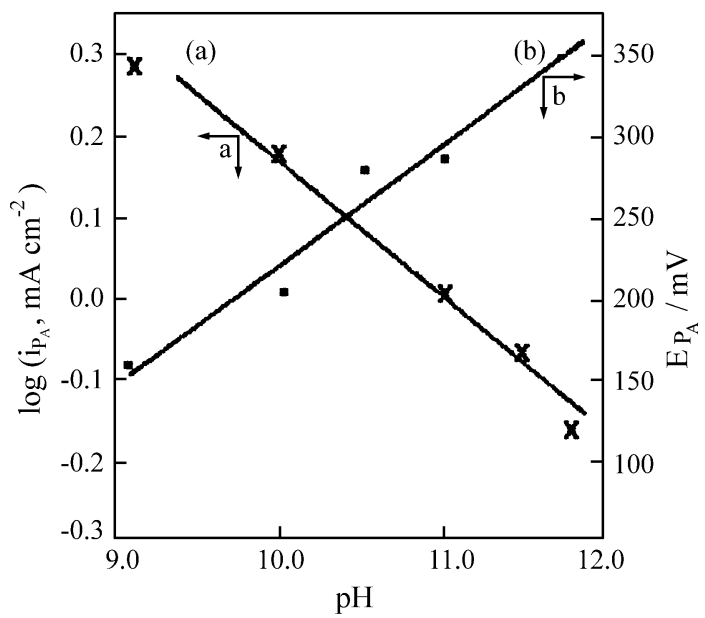

Figure 6.2. a. Anodic peak current density as a function of $\mathrm{pH}$. b. Variation of anodic peak potential with $\mathrm{pH}$.
$(0.1 \mathrm{~mol} / \mathrm{L})$ concentrations, a value of -0.20 was found for the reaction order in relation to the $\mathrm{pH}$, showing that this factor also contributes to the inhibition of the metal oxidation, but in a less remarkable way.

The surface fraction covered with borate species has been evaluated for iron in perchlorate solutions containing different amounts of borate and data were fitted to a Langmuir isotherm. This isotherm is defined by the expression:

$$
\frac{\mathrm{C}_{\text {borate }}}{\theta}=\frac{1}{\mathrm{~K}_{\text {adsorption }}}+\mathrm{C}_{\text {bor ate }}
$$

where $\mathrm{C}_{\text {BORATE }}$ is the borate anion concentration in $\mathrm{mol} / \mathrm{L}$; $\mathrm{K}_{\text {adsorption }}$ is the equilibrium constant of the adsorption / desorption process and $\theta$ is the fraction of the electrode surface covered by the adsorbed species. This $\theta$ can be determined by:

$$
\theta=\frac{\left(\mathrm{i}_{\mathrm{o}}-\mathrm{i}_{\mathrm{i}}\right)}{\mathrm{i}_{\mathrm{o}}}
$$

where $i_{o}$ is the anodic current density in absence of borate and $i_{i}$ is the anodic current density in different concentrations of this anion, evaluated at a constant potential $(-200 \mathrm{mV})$ before the anodic peak $\mathrm{P}_{\mathrm{A}}$. From Figs. 1 and $2, i_{o}$ and $i_{i}$ for different borate concentrations have been determined and the values for $\theta$ as a function of $\mathrm{C}_{\text {BORATE }}$ were calculated. Figure 7 represents $\mathrm{C}_{\text {BORATE }} / \theta$

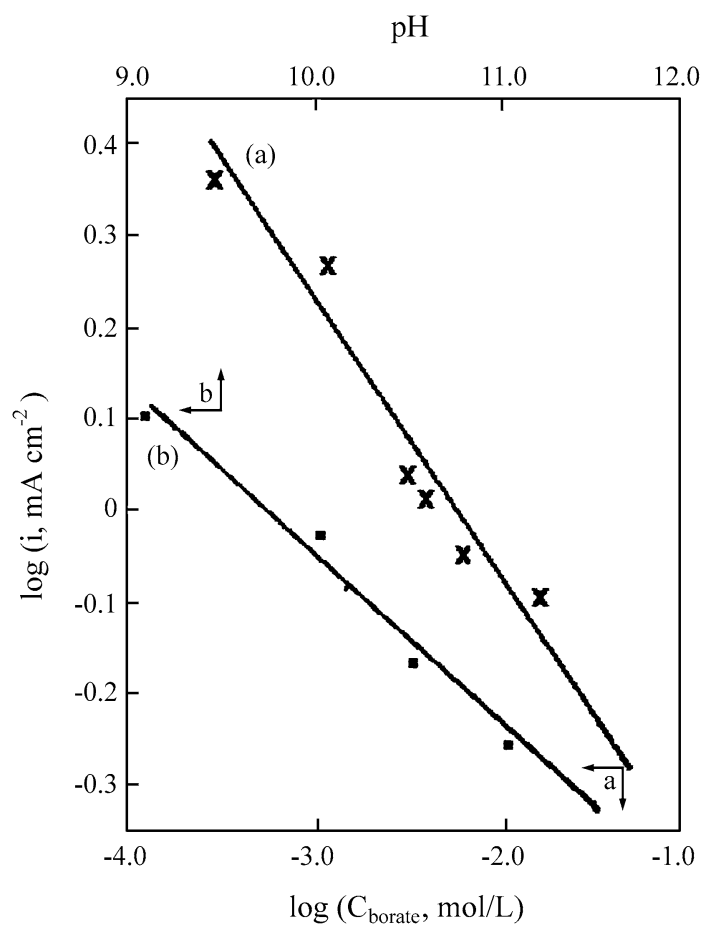

Figure 6.3. a. Variation of anodic current density (at $\mathrm{E}=-100 \mathrm{mV}$ ) with borax concentration.

b. Variation of anodic current density (at $\mathrm{E}=-100 \mathrm{mV}$ ) with $\mathrm{pH}$. 


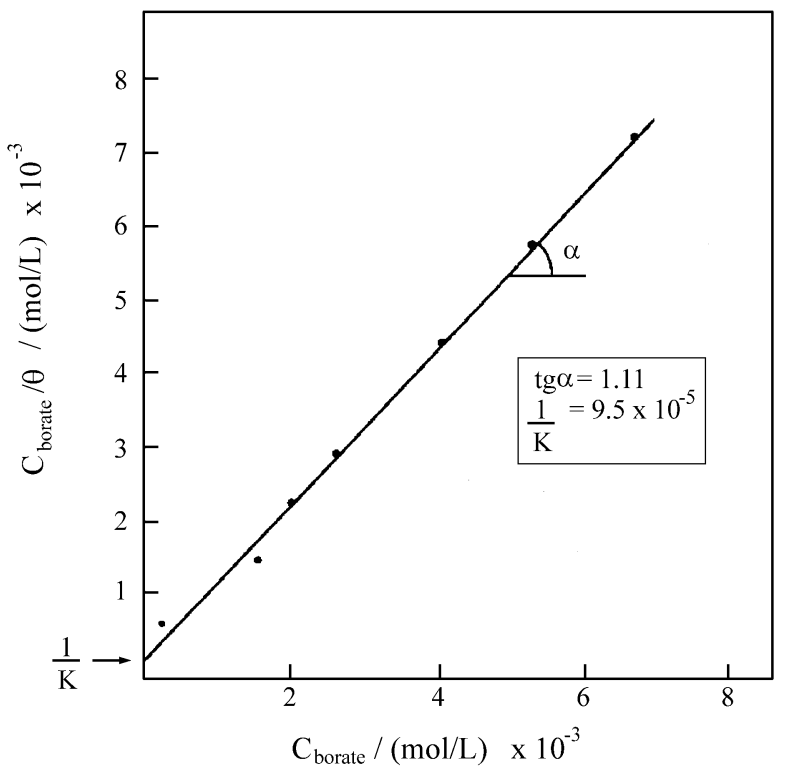

Figure 7. Langmuir isotherm for iron in $0.1 \mathrm{~mol} / \mathrm{L}$ sodium perchlorate (pH 9) with different borax concentrations.

against $\mathrm{C}_{\text {BORATE}}$. $\mathrm{A}$ linear behaviour is found as is foreseen by the Langmuir isotherm with a linear correlation coefficient of 0.9999 . The straight line slope value (1.11) is near to the theoretical value (1.0). The linear coefficient $\left(1 / K_{\text {adsorption }}\right)$ permits the evaluation of $K_{\text {adsorption }}$, resulting in a value of $1.05 \times 10^{4}$. The free energy variation for the adsorption process defined as $\Delta \mathrm{G}^{0}=-\mathrm{RT} \ln \mathrm{K}_{\text {adsorption, }}$ resulted in $-5.5 \mathrm{kcal} / \mathrm{mol}$ for the experimental conditions of this paper. This value indicates that the interaction between borate ion and the electrodic surface occurs by chemical adsorption.

\section{Conclusions}

The electrochemical behaviour of iron in the slightly alkaline solutions investigated depends on the anion present in solution. In the presence of perchlorate, one anodic peak $\left(\mathrm{P}_{\mathrm{A}}\right)$ and one cathodic peak $\left(\mathrm{P}_{\mathrm{C}}\right)$ are observed. In the presence of only borate, three anodic shoulders $\left(\mathrm{P}_{\mathrm{I}}, \mathrm{P}_{\mathrm{II}}\right.$ and $\mathrm{P}_{\text {III }}$ ) and one cathodic current region are observed with smaller current densities than in the perchlorate medium. These anodic shoulders in the medium containing only borate may be related to film formation reactions with different kinetic controls. Small amounts of borate added to perchlorate solution change the voltammetric profile. The anodic peak $\mathrm{P}_{\mathrm{A}}$ as well as the cathodic peak $\mathrm{P}_{\mathrm{C}}$ diminish and their potentials are shifted to more positive values. Thus there is a meaningful decrease of the total anodic charge for passivation of iron and an increase of the passivation efficiency in this medium. During the potentiodynamic experiments, when the electrode potential is cycled, the remaining film which had not been totally reduced in the previous scan, makes the passivation even more efficient, probably as it offers nucleation sites for the continuous growth of the oxide film. The RRDE experiments showed that borate anions, even in small quantities, inhibit iron dissolution. This property is due not only to its buffering capacity, that maintains the alkaline $\mathrm{pH}$ close to the electrode, but also to its chemical adsorption on the metallic surface, according to a Langmuir isotherm, stimulating the formation of a better film of passive oxide that obstructs dissolution.

\section{References}

1. Jovancicevic, V.; Kainthla, R.C.; Tang, Z.; Yang, B.; Bockris, J.O’M. Langmuir 1987, 3, 388.

2. Kozlowski, W.; Flis J., Corros. Sci. 1988, 28, 787.

3. Acosta, C.A.; Salvarezza, R.C.; Videla, H.A.; Arvia, A.J. Corros Sci. 1985, 25, 291.

4. Vela, E.M.; Vilche, J.R.; Arvia, A.J. J. of Appl. Electrochem. 1986, 16, 490.

5. Szklarska-Smialowska, Z.; Kozlowski, W. J. Electrochem. Soc. 1984, 131, 234.

6. Szklarska-Smialowska, Z.; Kozlowski, W. J. Electrochem. Soc. 1984, 131, 499.

7. Kozlowski, W.; Szklarska-Smialowska, Z. J. Electrochem. Soc. 1984, 131, 723.

8. Kozlowski, W.; Flis, J. Corros. Sci. 1991, 32, 861.

9. Rubim,J. J. Electrochem. Soc. 1993, 140, 1601.

10. Rubim, J.; Dunnwald, J. J. Electroanal. Chem. 1989, $258,327$.

11. Bhardwaj, R.C.; González-Martin, A.; Bockris, J.O'M. J. Electrochem. Soc. 1991, 138, 1901.

12. Bardwell, J.A.; MacDougall, B. J. Electrochem. Soc. 1988, 135, 2157.

13. MacDougall, B.; Bardwell, J.A. J. Electrochem. Soc. 1988, 135, 2437.

14. Hurlen, T.; Gunvaldsen, S.; Blaker, F. Electrochim. Acta 1984, 29, 1163.

15. Fischer, M.; Gruner, W.; Reinhardt, G. Corros. Sci. 1975, 15, 275.

16. Ogura, K. J. Electroanal. Chem. 1977, 79, 149.

17. Goetz, R., Mitchell, D.F.; MacDougall, B.; Graham, M.J. J. Electrochem. Soc. 1987, 134, 535.

18. Martini, E.M.A.; Amaral, S.T.; Muller, I.L. J. Braz. Chem. Soc. 1995, 6, 77.

19. Levich,V.G. Physichemical Hydrodynamics, p. 60, Prentice Hall, New Jersey, 1962.

20. Bard, A.J.; Faulkner, L.R. Electrochemical Methods, p. 280, John Wiley \& Sons, New York, 1980.

21. Albery, J.; Hitchmann, M.L. Ring Disc Electrode, p. 95, Clarendon Press, Oxford, 1971.

22. D‘Alkaine, C.V.; Souza, L.M.M. de; Nart, F.C. Corros. Sci. 1993, 34, 129. 
23. Albani, O.A.; Zerbino, J.O.; Vilche, J.R.; Arvia, A.J. Electrochim. Acta 1986, 31, 1406.

24. Juanto,S.; Zerbino, J.O.; Miguez, M.I.; Vilche, J.R.; Arvia, A.J. Electrochim. Acta 1987, 32, 1743.

25. Albani, O.A.; Gassa, L.M.; Zerbino, J.O.; Vilche, J.R.; Arvia, A.J. Electrochim. Acta 1990, 35, 1437.

26. Castro, E.B.; Vilche, J.R.; Arvia, A.J. Corros. Sci. 1991, 32, 37.

27. Schrebler-Guzman, R.S.; Vilche, J.R.; Arvia, A.J. J. Appl. Electrochem. 1981, 11, 551.
28. Juanto, S.; Schrebler, R.S.; Zerbino, J.O.; Vilche, J.R.; Arvia, A.J. Electrochim. Acta 1991, 36, 1143.

29. Seo, M.; Sato, N. Corros. Sci. 1978, 18, 577.

30. Seo, M.; Sato, N.; Lumsden, J.B.; Staehle, R.W. Corros. Sci. 1977, 17, 205.

31. Amaral, S.T.; Muller, I.L. Corros. Sci. 1999, 41, 759. 32. Amaral, S.T.; Muller, I.L. Corros. Sci. 1999, 41, 747. 33. Amaral, S.T.; Muller, I.L. Corrosion 1999, 55, 17. 34. Génin, J.M.R. et al. Corros. Sci. 1996, 38, 1751. 